\title{
RESEÑA: HISTORICAL AND THEORETICAL APPROACHES TO ENGLISH SATIRE. JUAN FRANCISCO ELICES AGUDO
}

\author{
Alberto Lázaro Lafuente*
}

\section{Elices Agudo, Juan Francisco. 2004. Historical and Theoretical Approaches to English Satire. Muenchen: Lincom Europa. 121 páginas. ISBN: 3-89586-743-8.}

El estudio de los géneros literarios ha constituido a lo largo de los siglos uno de los más interesantes y polémicos desafíos de la crítica literaria. Dentro de este ámbito tan heterogéneo y complejo, la sátira ha merecido especial consideración. Después de los ya clásicos tratados sobre sátira que surgieron fundamentalmente en la década de los años sesenta, como The Power of Satire (1960) de Robert C. Elliott, The Anatomy of Satire (1962) de Gilbert Highet, The Satirist: His Temperament, Motivation, and Influence (1963) de Leonard Feinberg, The Plot of Satire (1965) de Alvin B. Kernan y The Fictions of Satire (1967) de Ronald Paulson, en los últimos años el interés por este tipo de literatura se ha mantenido vivo en muchas otras monografías, como Satire: A Critical Reintroduction (1994) de Dustin Griffin, Theorizing Satire: Essays in Literary Criticism (1995) editado por Brian A. Connery y Kirk Combe, y Satire (2001) de Jane Ogborn y Peter Buckroyd, por citar algunas de las más destacadas. En este contexto hemos de dar la bienvenida a la obra Juan Francisco Elices, Historical and Theoretical Approaches to English Satire, que surge con la sana intención de ayudar a comprender mejor el complejo entramado de la sátira, en este caso, en el ámbito de la literatura inglesa.

Escribir sobre sátira suele ser una empresa ardua y atrevida que exige adentrarse en una parcela de los géneros literarios muy complicada, donde no existe unanimidad sobre su definición, límites o rasgos característicos. En ocasiones el término "sátira" hace referencia a un género poético determinado, con unas características formales concretas, que cultivaron autores de diversas épocas, como Horacio, Juvenal, Dryden y Pope. En un sentido mucho más amplio, por sátira se entiende también aquella modalidad literaria que implica una actitud crítica en una obra de cualquier género que pretende censurar los males de la sociedad, sus individuos o instituciones. La obra de Juan Francisco Elices tiene precisamente como principal objetivo arrojar luz sobre la naturaleza, a menudo imprecisa y contradictoria, de este tipo de literatura. Para ello, no se limita únicamente a analizar las características y estrategias retóricas de la sátira, sino que también lleva a cabo

* Catedrático, Departamento de Filología Moderna, Universidad de Alcalá; $\square$ alberto.lazaro@uah.es. 
una sucinta, pero útil, revisión histórica de la producción satírica, desde sus orígenes hasta la actualidad.

El trabajo presenta una estructura clara y sencilla que sirve para el buen desarrollo del objetivo que se ha marcado. El primer capítulo ofrece la revisión histórica mencionada anteriormente, donde se indaga sobre las primeras muestras del espíritu satírico. Siguiendo las teorías de críticos como Robert Elliott, se sitúa los inicios de la sátira en diferentes sociedades primitivas, como la de los esquimales, la de algunos países árabes y la de la Irlanda precristiana, en donde se han podido localizar algunas manifestaciones literarias que contienen diatribas o críticas violentas contra personas. De esta forma, se da un primer paso hacia la definición de sátira, optando por una concepción amplia en la que se incluyen discursos próximos a la invectiva y al libelo. El recorrido histórico continúa después por las formas más depuradas de la sátira clásica, tanto griega como romana, para adentrarse después en las diferentes formas que ha adoptado este género en la literatura inglesa, desde los cuentos medievales de Geoffrey Chaucer, hasta narrativa satírica de carácter político o feminista que a finales del siglo XX han desplegado autores como Julian Barnes y Angela Carter. Este capítulo ofrece muy sucintamente una esclarecedora panorámica de la diversidad de formas, temas y tonos que puede abrazar la sátira.

Una vez que se han mostrado las múltiples caras que puede adoptar el espíritu satírico, el capítulo segundo busca una aproximación al concepto de sátira y una clasificación coherente de sus manifestaciones. Con buen criterio, Juan Francisco Elices sigue una orientación inductiva, de modo que de la descripción de los casos particulares de sátira expuestos en el primer capítulo, se asciende a la formación de la idea general, o lo que es lo mismo, a la formulación de los rasgos definitorios de la sátira. Para ello, parte de las teorías de Alistair Fowler, quien considera a la sátira como un "modo", más que un "género" literario, dado su carácter cambiante y heterogéneo. Posteriormente, se hace una interesante revisión de diferentes definiciones de sátira, desde las que ofrecen los diccionarios de términos literarios hasta las que formula la crítica especializada; de esta forma Juan Francisco Elices logra una abstracción y concreta los elementos comunes y característicos de la sátira. Su planteamiento, como él mismo reconoce, es ecléctico y combina ideas propuestas por la denominada escuela de Chicago (Edgard Rosenheim y Sheldon Sacks), así como enfoques más retóricos y antropológicos de la escuela de Yale (Alvin Kernan, Robert Elliot y Maynard Mack): "My understanding of satire interweaves the rhetorical and historical approaches of the Yale and Chicago School of criticism respectively, that is it encompasses an all-embracing combination of its formal aspects, which operate as filters of raw expressions akin but divergent from satire, and the necessary connections with the socio-historical context that intervenes in the process of satiric writing" (58). Esta postura es muy sensata y le permite ofrecer una concepción de la sátira, plausible y coherente. Así pues, se describe la sátira como un modo literario que tiene como objetivo fundamental denunciar o criticar los vicios y los defectos humanos, en ocasiones con un propósito moral corrector, otras veces con la simple intención de castigar al infractor. En cuanto a los tipos de sátira, atendiendo a los objetivos contra los que se dirigen los dardos del escritor satírico, se establece una tipología temática y se distingue entre la sátira política, la sátira religiosa y la sátira social o de costumbres, siendo la primera la que más practicantes ha 
tenido a lo largo de la historia. En este sentido, es interesante la conexión que se introduce en este capítulo entre el desarrollo de la sátira política y la práctica de la censura.

El tercer y último capítulo se centra en el estudio de las estrategias retóricas a las que recurre el escritor satírico para que su crítica sea más efectiva y alcance altura literaria. Son estrategias que pueden aparecer en otros tipos de discursos literarios, aunque algunas de ellas, como la ironía o la parodia, se hayan vinculado tradicionalmente a la sátira. Sin duda alguna, la ironía siempre ha sido una buena aliada de la sátira; cuando se desea criticar algo o a alguien la oblicuidad y el ingenio suelen ser más efectivos que el simple insulto y la invectiva. Así lo reconoce Juan Francisco Elices, quien dedica un apartado a esta estrategia, destacando fundamentalmente la ironía verbal y la ironía dramática. Por otra parte, se distingue a la parodia como otra estrategia cardinal de la sátira. A la hora de determinar los tipos de parodia, aunque se reconoce la validez de algunas clasificaciones tradicionales como la de Highet en The Anatomy of Satire o la de Feinberg en Introduction to Satire, aquí se prefiere la distinción que Gérard Genette ofrece en Palimpsests: Literature in the Second Degree (1982) entre el denominado "travesti", el pastiche satírico y la parodia propiamente dicha. Todo ello está relacionado con otras estrategias retóricas que se describen en este capítulo, como son el ingenio y el elemento fantástico. Es precisamente en este último aspecto en donde Juan Francisco Elices aporta un análisis más detallado, deteniéndose especialmente en el empleo de la caricatura, la animalización, la utopía y la distopía. Al final, se consigue el objetivo marcado y se logra determinar claramente, no sólo la naturaleza del espíritu satírico, sino los mecanismos retóricos a los que generalmente recurre esta modalidad literaria.

La presentación de este libro es impecable, con una redacción clara y bien organizada. Se incluye una amplia bibliografía, adecuada y actualizada, que el autor maneja con gran destreza, incluyendo citas muy apropiadas. Asimismo, tanto el análisis de los textos satíricos del primer capítulo, como el estudio teórico de la sátira se llevan a cabo con objetividad, minuciosidad, coherencia y rigor científico. Como sugerencia para posibles futuras ediciones, se podría recomendar la inclusión de un índice onomástico y analítico al final del libro; dado el elevado número de autores, obras y temas que se tratan, un índice de estas características podría ser muy útil para localizar rápidamente referencias concretas en el texto. Con todo, estamos ante un trabajo que refleja una gran madurez intelectual, una sólida formación investigadora y una aguda visión crítica de textos literarios. Es, sin duda, un libro de gran interés para todos aquellos que deseen adentrarse en el estudio de los géneros literarios en general, así como para los que quieran obtener una panorámica clara y precisa de la naturaleza de la sátira y sus manifestaciones en la literatura inglesa. 